\title{
Understanding Families in India: A Reflection of Societal Changes
}

\author{
Reeta Sonawat ${ }^{1}$ \\ SNDT Women's University, Bombay, India
}

\begin{abstract}
Literature on family studies in India has grown to a large extent in the last two decades, although such studies are scattered. This article presents socio-demographic data on families in India aiming to provide bases for analyzing research, particularly in the area of family development. Indian families are classified as patrilineal and matrilineal according to the lineage or descent by father or mother. The family structure is conceptualized as the configuration of role, power, and status and relationships in the family which depends upon the families socio-economic background, family pattern, and extent of urbanization. Marriage practices are emphasized covering subjects such as marriage patterns, selection of marriage partner, age at marriage, age at consummation of marriage, marriage rituals, financial exchanges and divorce. In spite of urbanization and industrialization in the contemporary Indian society, the family institution continues to play a central role in the lives of people.
\end{abstract}

Key words: Indian families; family legislation; Indian constitution; family relations.

\section{Compreendendo as Famílias na Índia: Uma Imagem das Mudanças na Sociedade}

\begin{abstract}
RESUMO - A literatura sobre estudos da família na Índia tem crescido amplamente nas últimas décadas, embora seja considerada, ainda, insuficiente. Este artigo apresenta dados sócio-demográficos sobre as famílias indianas visando fornecer embasamento para análises de pesquisas, particularmente na área de desenvolvimento familiar. As famílias são classificadas como patrilinear e matrilinear, em função da linhagem ou descendência paterna ou materna, respectivamente. A concepção de estrutura familiar está relacionada à configuração de papéis, poder, status e relações na família e depende, sobretudo, do nível sócio-econômico das famílias, do padrão familiar e da extensão da urbanização. As práticas maritais são enfatizadas em tópicos como padrões de casamento, seleção do(a) parceiro(a) matrimonial, idade para consumação do casamento, rituais matrimoniais, arranjos financeiros e divórcio. A despeito da urbanização e industrialização na sociedade indiana contemporânea, a instituição família continua desempenhando um papel central na vida das pessoas.
\end{abstract}

Palavras-chave: famílias indianas; legislação familiar; constituição indiana; relações familiares.

The family in India is often understood as an ideal homogenous unit with strong coping mechanisms. It is a basic, cohesive, and integral unit of the larger social systems. Moreover, families in a large and culturally diverse country such as India have plurality of forms that vary with class, ethnicity, and individual choices. Its members are bound by interpersonal relationships in a wider network of role and social relations. It is considered a link between community and change (Tata Institute of Social Sciences - TISS, 1993). The family is the basic and important unit of society because of the role it plays in generation of human capital resources and the power that is vested in it to influence individual, household, and community behavior (Sriram, 1993). It is, therefore, a basic unit of study in most social sciences disciplines, such as sociology, psychology, economics, anthropology, social psychiatry, social work or human development.

1 Correspondence concerning this article should be addressed to Reeta Sonawat. Department of Human Development, Post-Graduate Studies \& Research, S. N. D. T. Women's University. Santacruz (W), Mumbai - 400 049, India. E-mail: hms@tifr.res.in
The family is the first line of defense especially for children and a major factor in their survival, health, education, development, and protection. It is also a major source of nurturance, emotional bonding and socialization, and a link between continuity and change. It has the major potential to provide stability and support when there are problems. Human development can, thus, be enhanced by enriching family life (Desai, 1995a).

Families in India are undergoing vast changes like increasing divorce and separation rates, domestic violence, inter-generational conflicts, social problems of drug abuse, juvenile delinquency etc. These changes indicate the inability to cope with the pressures of the modern life. Yet, the majority seem to have survived and are able to modify, adjust and adapt to changing social norms, values and structures, and have demonstrated a unique strength in keeping together despite the growing stress and strain.

In recent decades family studies have undergone several developments. Family studies in India are viewed within the institutional framework of particular society. In each society, families vary in their extent of adjustment to accept norms owing to the family interaction pattern and external forces. The present article reviews the rapidly changing family sce- 
nario. Research studies on the family conducted in the past few decades in India have focused on various dimensions of family life (that is, multiple forms, structure, size, changing functions, and individual roles). Such studies suffer from a lack of applied value and multidisciplinary approach. The following review reflects these concerns by focusing on the researches conducted on the various aspects.

\section{Demographic and Constitutional View of Indian Families}

\section{Population and Households}

India's population of 846 million (Ministry of Home Affairs - Social Studies Division, 1991) lives in 152 million households. These are grouped into 112 million rural and 40 million urban families. Although the urban population is a quarter of the total, its increase has been significantly large and its increasing impact on the family is inevitable. One of the stark realities in India is that life is harsh due to lack of basic, civic, educational, health, and other infra-structural facilities in both rural and urban areas. Despite the fact that the pace of urbanization has started accelerating, the overwhelming majority of Indian families is still rural based and $43 \%$ of these live below the poverty line. Nearly half of the urban poor families live in slums (Gulati, 1995).

\section{Religious Composition of the Households}

The Indian population can be divided on the basis of its religious composition. In 1981, the overwhelming majority forming $82.35 \%$ were Hindus followed by $11.74 \%$ Muslims, $2.44 \%$ Christians, $1.97 \%$ Sikhs, and $1.57 \%$ others. The Hindus are divided into numerous castes and sub-castes. Although dogmatically Islam, Christianity, Buddhism, and Jainism do not approve the caste division, in practice castes or caste like groups also exist in each of them.

Most Hindu castes practice the patrilineal family system, although in the south-western state of Kerala the Nairs and a few other castes practice, by tradition, the matrilineal family system. Similarly, the Garo and Khasi tribes in north-eastern India are matrilineal though their matriliny is, in some ways, different from that of the Nairs. "From joint family to elementary farmer," this has been a slogan to summarize changes in the family in India during modern times.

\section{Family According to Indian Constitution}

India has distinct personal laws for families belonging to different religions and, therefore, do not have agreed upon goals about this important aspect of civic life. Hindus, Muslims, Christians, Sikhs, Jews, and Parsis, each community has its own personal law which covers matters of personal relations and family practices such as marriage and divorce, adoption, maintenance, guardianship and custody of children, and inheritance and succession. As these laws draw from the respective religious norms, they often perpetuate traditional patriarchal norms, and slow down the process of reforms.

Although Article 44 of the Constitution states that "The State shall endeavor to secure for the citizens a uniform civil code throughout the territory of India" (Pylee, 1979, p. 471), attempts at enacting secular family laws that apply to family practices of all Indians invariably go through prolonged and bitter debate. The few attempts that have been successful have led to secular family laws such as the Child Marriage Restraint Act, 1929; the Medical Termination of Pregnancy Act, 1972; Special Marriage Act, 1974; Dowry Prohibition Act, 1961, and provisions made in the Criminal Procedure Code and Indian Penal Code. However, the interpretation and implementation of these laws leave much to be desired. Thus, there exist myriad policies for the family and its members. However, separate policies for family size, family laws, housing, children, youth, and so on, have independent objectives. In the absence of an overall family policy with explicit goals for the family, these policies affect the family in diverse ways with sometimes contradictory and negative outcomes.

During the post-independence years, studies on the Indian family were undertaken to understand the changes in family size, type, and composition as a result of the impact of modernization and urbanization. This period was characterized by many legislation concerning the Indian family (see Table 1). The most important piece of legislation was the one passed in 1956, dealing with succession, namely the Hindu Succession Act (Pylee, 1979). It gave a woman full ownership in the property inherited or acquired by her. Women inherit property equally with men now. The other important measures were the Hindu Marriage Act of 1955, the Dowry Prohibition Act of 1961, and Divorce Reform Act of 1969 (Pylee, 1979).

\section{Family Structure and Composition - An Overview}

Family may be broadly defined as a unit of two or more persons united by marriage, blood, adoption, or consensual union, in general consulting a single household, interacting and communicating with each other (Desai, 1994). Figure 1 shows the conceptual framework of family structure in India.

Right from ancient times, family, caste, and community have dominated the entire texture of Indian society. Family has been the dominating institution both in the life of the individual and in the life of the community.

There was virtually no scope to exit without being a member of a family. According to Census of India (Ministry of Home Affairs, 1991), Indian families comprise largely of nuclear family structure with joint families forming about a fifth of the total households (Census of India, 1981). Kolenda (1987) reviewed the various studies on structures of families in India (see Table 2). She classified the families into several types of family structures: Single member households (a man or woman in one household), nuclear pair (only 
Table 1

Legislation Related to Indian Family

\begin{tabular}{|c|c|c|}
\hline Year & Legislation & Purpose \\
\hline 1829 & 'Sati' Regulation & $\begin{array}{l}\text { A regulation declaring the practice of 'Sati' } \\
\text { or burning or burying of Hindu widows } \\
\text { illegal, and punishable by criminal courts }\end{array}$ \\
\hline 1856 & $\begin{array}{l}\text { The Hindu Widow } \\
\text { Re-marriage Act }\end{array}$ & $\begin{array}{l}\text { Legalized the remarriage of Hindus of all } \\
\text { Castes }\end{array}$ \\
\hline 1870 & $\begin{array}{l}\text { Abolition of female } \\
\text { infanticide }\end{array}$ & \\
\hline 1891 & Age of Consent Act & Age of consent from 10 to 12 years \\
\hline 1929 & $\begin{array}{l}\text { Sarada Act A Child } \\
\text { marriage Restraint } \\
\text { Act }\end{array}$ & $\begin{array}{l}\text { Minimum age at marriage for girls raised to } \\
14 \text { years }\end{array}$ \\
\hline 1937 & $\begin{array}{l}\text { The Hindu } \\
\text { Women's Rights to } \\
\text { Property Act }\end{array}$ & $\begin{array}{l}\text { Gave the Hindu widow right to intestate } \\
\text { succession equal to a son's share in regard } \\
\text { to her husband's property liable to } \\
\text { devolution by succession. }\end{array}$ \\
\hline 1955 & $\begin{array}{l}\text { The Hindu } \\
\text { Marriage Act }\end{array}$ & $\begin{array}{l}\text { Minimum age of marriage as } 18 \text { for boys } \\
\text { and } 15 \text { years for girls } \\
\text { Until the passage of this act every male, in } \\
\text { theory, was free to marry a number of } \\
\text { women } \\
\text { The act of } 1955 \text { allows women to divorce if } \\
\text { they are married to men who are insane, } \\
\text { affiliated with leprosy or venereal diseases. } \\
\text { Legalizes marriage between members of the } \\
\text { same gotra. Provides that a marriage may } \\
\text { be solemnized between any two Hindus if } \\
\text { neither has a spouse living }\end{array}$ \\
\hline 1956 & $\begin{array}{l}\text { The Hindu } \\
\text { Succession Act }\end{array}$ & $\begin{array}{l}\text { Converted the limited life estate of a Hindu } \\
\text { female to full and absolute owner }\end{array}$ \\
\hline 1956 & $\begin{array}{l}\text { The Hindu } \\
\text { Maintenance Act }\end{array}$ & $\begin{array}{l}\text { Invested certain rights of adoption which } \\
\text { she had not enjoyed before }\end{array}$ \\
\hline 1956 & $\begin{array}{l}\text { The Hindu } \\
\text { Minority and } \\
\text { Guardianship Act }\end{array}$ & $\begin{array}{l}\text { Hindu women are empowered under this act } \\
\text { to choose guardians for the adopted } \\
\text { children to choose }\end{array}$ \\
\hline 1961 & Dowry Prohibition & Prohibits the giving or taking of dowry \\
\hline 1956 & $\begin{array}{l}\text { Hindu Succession } \\
\text { Act }\end{array}$ & $\begin{array}{l}\text { Right to per capita partition was extended } \\
\text { to matrilineal families in Malabar also }\end{array}$ \\
\hline
\end{tabular}

Note. From "Women and family in India - continuity and change", by L. Gulati (1995). Indian Journal Social Work, 56, p. 134-154. Copyright 1995 by Tata Institute of Social Sciences, Deonar, Bombay - 400088 , India. Adapted with permission.

married couple), nuclear family (a married couple with or without children) and forms of nuclear family (broken nuclear - a fragment of a former nuclear family, e.g., a widow with unmarried children living together; supplemented nuclear - a nuclear family plus one or more unmarried / separated / widowed relatives of the parents, other than married children), collaterally extended (two or more married couples among whom there is a sibling bond, normally brothers plus their unmarried children), supplemented collateral joint (a collateral joint family with unmarried, divorced, widowed relatives, typically such supplemented relatives are the widowed mother or widower father or an unmarried sibling), lineal extended (two couples between whom there is a lineal link, usually between parents and married son or married daughter), supplemented lineal joint (a lineal joint family plus unmarried, divorced or widowed relatives who do not

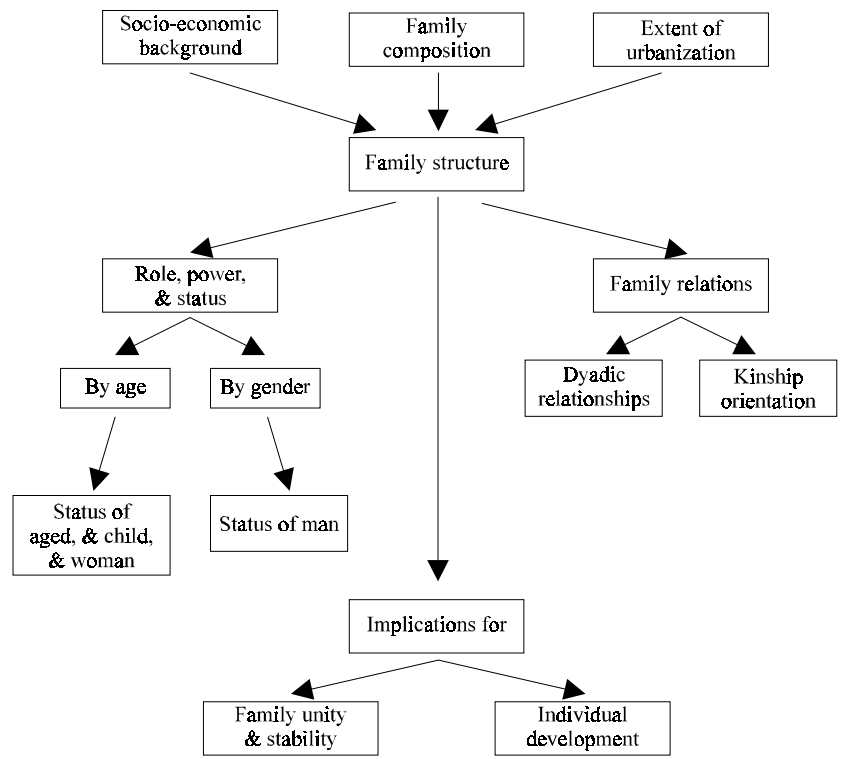

Figure 1. Diagram of the conceptual framework of family structure. From Conceptual frameworks for understanding family. Enhancing the role of the family as an agency for social and economic development (Unit for Family Studies Report, pp. 16-41), by Desai, 1994, Bombay, India: TISS. Copyright 1994 by Tata Institute of Social Sciences, Deonar, Bombay 400 088, India. Adapted with permission.

Table 2

Types of Household

\begin{tabular}{lrrr}
\hline Household type & $\begin{array}{c}\text { Total } \\
\text { \% }\end{array}$ & $\begin{array}{c}\text { Rural } \\
\text { \% }\end{array}$ & $\begin{array}{c}\text { Urban } \\
\text { \% }\end{array}$ \\
\hline Single Member & 5.80 & 5.15 & 7.91 \\
Nuclear Pair & 4.98 & 4.91 & 5.20 \\
Nuclear & 38.74 & 37.88 & 41.57 \\
Broken Nuclear & 4.50 & 4.58 & 4.24 \\
Supplemented Nuclear & 16.48 & 16.81 & 15.44 \\
Supplemented Broken Nuclear & 5.61 & 5.76 & 5.13 \\
Lineally Extended & 16.62 & 17.65 & 13.23 \\
Collaterally Extended & 0.17 & 0.11 & 0.36 \\
\hline
\end{tabular}

Note. From "Women and family in India - continuity and change", by L. Gulati (1995). Indian Journal Social Work, 56, p. 134-154. Copyright 1995 by Tata Institute of Social Sciences, Deonar, Bombay - 400088 , India. Adapted with permission.

belong to either of the lineally linked nuclear unmarried brother), lineal collateral joint (three or more couples linked lineally or collaterally, typically, parents and their married sons plus the unmarried children of the couple), supplemented lineal collateral joint (a lineal collateral joint family plus unmarried, widowed, separated relatives who belong to none of the nuclear families lineally and collaterally linked) and an unclassified category.

\section{Family Characteristics}

Most of the demographic characteristics, socio-religious beliefs and practices influence the nature of the Indian family system and also reflect the changes taking place in it. The Indian family is by and large patriarchal in structure (Kapadia, 1982). In a patriarchal family set up, all male 
members, that is, husband, elder brother and father, perform duties like decision making for the rest of the family, and their physical and moral protection. This patriarchal set up is changing slowly towards equalitarian interaction among the educated, urban middle classes, and also among some rural set ups (Mullatti, 1995). Even in matrilineal and matrilocal cultures patriarchy seems to be prevalent in the form of power held by the brother and not by the women herself.

Patriarchal structure - roles, responsibility, control, and distribution of resources within the family are strictly determined by age, gender and generation. The establishment of the family system is believed to be mainly for the fulfillment of religious obligations like ancestor worship, begetting a male child and passing social religious traditions to the next generation.

Patriarchal families continue to be patrilineal and patrilocal; and the lineage is based on the father's family. The Hindu Code Bill of 1954-1956 (as cited in Pylee, 1979) has introduced a few changes in this system by allowing some share of the property to the daughter, inter-religion and -caste marriage rights, equal rights to women with respect to adoption, divorce, and remarriage.

One of the few surviving bastions of women power are the Khasis of Meghalaya with a matrilineal system of family. The power, wealth, and rights of inheritance are vested in the women. Basaiawmoit (1987), however, found that with passage of time the matrilineal system has undergone dramatic change due to education, technology and politics. The younger generation is raising the issue to move towards some form of patrilineal system though the elders feel the existing matrilineal form should continue (Saiborne, 1995).

A significant aspect noted is the new economic order merging with the traditional pride in jointly owned property. Today's big business houses like the Tata and Birla are all family ventures. So instead of the breaking of joint families due to urbanization and industrialization, more joint families are found in urban business communities (Desai, 1980). Married brothers may have separate houses, but run a common business and meet regularly at a variety of family rituals. Hence, a large number of families in India are described as being functionally joint, with separate residence.

In rural India, though agriculture is the main occupation, there are not many large land holdings. This, and modern education and other related factors, make it difficult to maintain joint families (Mullatti, 1995).

\section{Alternate Family Pattern}

The term 'alternate family pattern' suggests family patterns that result from personal circumstances outside one's control (death of a partner, infertility) or from certain socioeconomic conditions such as male migration and work participation of women. In such circumstances people are forced to adapt family patterns that suit their conditions. Such families are, therefore, not mere lifestyle experimentations but come out of certain circumstances (Bharat, 1994). In the Indian context, most family variations that are prevalent to- day are a result of such personal or socio-economic circumstance. Experimental or chosen life styles like living without marrying and being childless voluntarily are restricted to an extremely small group of people. The unwritten rule was, and still is, that all marriages must result in children and preferably male children (Gulati, 1995). The following may be considered the most commonly observed family variations in India: single parent families, female headed households, dual earner/career families, childless families, and adoptive families.

The range of family variations seems limited. In the West, the family patterns reflect experimentation with lifestyles and seeking of alternatives to existing patterns. In contrast, the Indian family variations suggest adaptation to socio-economic and personal circumstances that is necessary for survival.

\section{Marriage and Divorce}

According to the traditional Hindu view, marriage is a sacrament. A number of studies have been conducted in an attempt to examine the impact of modern trends represented by formal education, urbanization, and industrialization. Changing patterns are being observed in areas such as age at marriage, inter-caste marriage, arranged versus love matches, matching horoscopes. Inter-religious marriages do take place in India and there is a special law to support such marriages. However, they are extremely small in number. For the vast majority of people, marriage is always within one's religious group, and the family also, therefore, prevails within it. These religious groups have evolved since the turn of this century as legal, and some even as constitutional, entities and this has important consequences for the nature of marriage and family in each of them. Although one of the directive principles of state policy laid down in the constitution determines that the state shall endeavor to secure for the citizens a uniform civil code throughout the territory of India, there is as yet no uniform law of family and marriage for all religious groups. There is enormous social and cultural diversity, hence the gap between law and custom within each religious group. The major mate selection pattern continues to be arranged by elders and parents even among highly educated urban communities and castes, although gradual change is observed here too.

The mean age of marriage for men is 23.5 years and women is 18.4 years, the difference being 5.1 years (see Table $3)$. Higher age of groom is suggestive of more power, experience and better economic status. The age difference between male and female varies substantially (Mullati, 1995).

\section{Values of Youth Towards Marriage}

The value expressed by boys and girls towards marriage in the contemporary society has changed. Table 4 shows that girls differed from their counterparts in expressing "marriages should be decided by the elders". On the other hand, boys strongly felt that selection of marriage partner should 
Table 3

Mean Age of Marriage

\begin{tabular}{lccc}
\hline Decade & Male & Female & Difference \\
\hline $1951-1961$ & 21.76 & 15.43 & 6.33 \\
$1964-1971$ & 22.67 & 17.10 & 5.57 \\
$1971-1981$ & 23.43 & 18.39 & 5.04 \\
\hline
\end{tabular}

Note. From "Women and family in India - continuity and change", by L. Gulati (1995). Indian Journal Social Work, 56, pp. 134-154. Copyright 1995 by Tata Institute of Social Sciences, Deonar, Bombay - 400088 , India. Adapted with permission.

Table 4

Perception of Youth Towards Marriage

\begin{tabular}{|c|c|c|c|c|c|}
\hline \multirow{2}{*}{ Statements } & \multicolumn{2}{|c|}{ Boys $(n=80)$} & \multicolumn{2}{|c|}{ Girls $(n=89)$} & \multirow{2}{*}{$\mathbf{t}$} \\
\hline & M & SD & M & SD & \\
\hline $\begin{array}{l}\text { Marriage should be decided } \\
\text { by the elders }\end{array}$ & 3.18 & 1.50 & 3.93 & 0.96 & $3.88 * *$ \\
\hline $\begin{array}{l}\text { Selection of marriage partner } \\
\text { should be left to the boy/girls }\end{array}$ & 4.29 & 0.84 & 3.96 & 0.86 & $2.41 *$ \\
\hline $\begin{array}{l}\text { In choosing the marriage } \\
\text { partner preference should be } \\
\text { to nuclear family set up }\end{array}$ & 2.36 & 1.31 & 2.59 & 1.01 & 0.18 \\
\hline $\begin{array}{l}\text { Marriage should involve } \\
\text { match makes of matrimonial } \\
\text { bureau }\end{array}$ & 3.55 & 1.26 & 3.80 & 0.95 & 1.43 \\
\hline $\begin{array}{l}\text { Marriage should be } \\
\text { celebrated without much } \\
\text { delay after engagement }\end{array}$ & 2.69 & 1.34 & 2.78 & 1.14 & 0.45 \\
\hline $\begin{array}{l}\text { One should be allowed to } \\
\text { marry any person of his / her } \\
\text { liking }\end{array}$ & 2.74 & 1.39 & 2.48 & 1.09 & 1.31 \\
\hline Marriage is for social status & 2.99 & 1.38 & 2.85 & 1.21 & 0.66 \\
\hline $\begin{array}{l}\text { Marriage should provide } \\
\text { equal opportunity for } \\
\text { partners in decision making } \\
\text { process }\end{array}$ & 4.50 & 0.82 & 4.64 & 0.58 & 1.27 \\
\hline
\end{tabular}

Note. Judgments were made on a 5 point scale $(1=$ strong disagreement, 3 $=$ neutral, $5=$ strong agreement). From "Values of college youth towards marriage", by P. R. Sumangla and S. Hasalkar, 1999, Journal of Avinashlingam Deemed University, 9, p. 163. Copyright 1999 by Avinashlingam Institute for Home Science and Higher Education for Women - Deemed University, Coimbatore - 641 043, Tamil Nadu, India. Reprinted with permission.

$* p<.01 * * p<.05$

be left to statements the group did not differ in their values. This shows clearly that values towards marriage in general have not changed much among the present college youth. They are still in agreement with the conventional values.

\section{Moral values towards marriage}

Girls have expressed that certain behaviors in marriage are wrong. They strongly disagree with the action of indulging in sex before marriage and they consider it as a sin. Similarly they have also expressed a strong value system towards sex should be enjoyed only with married partner, and sexual
Table 5

Perception of Moral Value of Youth Towards Marriage

\begin{tabular}{|c|c|c|c|c|c|}
\hline \multirow{2}{*}{ Statements } & \multicolumn{2}{|c|}{ Boys $(n=80)$} & \multicolumn{2}{|c|}{ Girls $(n=89)$} & \multirow{2}{*}{ t } \\
\hline & $\mathbf{M}$ & SD & $\mathbf{M}$ & SD & \\
\hline $\begin{array}{l}\text { In marriage spouse's } \\
\text { virginity Should be } \\
\text { considered }\end{array}$ & 3.66 & 1.13 & 3.63 & 1.14 & 0.19 \\
\hline $\begin{array}{l}\text { Indulging in sex before } \\
\text { Marriage is a sin }\end{array}$ & 3.24 & 1.38 & 4.04 & 1.14 & $4.11 * *$ \\
\hline $\begin{array}{l}\text { Sex should be enjoyed only } \\
\text { with marriage partners }\end{array}$ & 3.83 & 1.31 & 4.18 & 0.82 & $2.08^{*}$ \\
\hline $\begin{array}{l}\text { Sexual relationship before } \\
\text { Marriage with a fiancé } \\
\text { lessens the respect after } \\
\text { marriage }\end{array}$ & 3.00 & 1.33 & 3.45 & 1.23 & $2.27 *$ \\
\hline $\begin{array}{l}\text { Having a child without } \\
\text { marriage Should be accepted }\end{array}$ & 2.43 & 1.36 & 2.45 & 1.45 & 0.11 \\
\hline
\end{tabular}

Note. Judgments were made on a 5 point scale $(1=$ strong disagreement, 3 $=$ neutral, $5=$ strong agreement). From "Values of college youth towards marriage", by P. R. Sumangla and S. Hasalkar, 1999, Journal of Avinashlingam Deemed University, 9, p. 164. Copyright 1999 by Avinashlingam Institute for Home Science and Higher Education for Women - Deemed University, Coimbatore - 641 043, Tamil Nadu, India. Reprinted with permission.

$* p<.01 \quad * * p<.05$

Table 6

Economic Value of Youth Towards Marriage

\begin{tabular}{|c|c|c|c|c|c|}
\hline \multirow{2}{*}{ Statements } & \multicolumn{2}{|c|}{ Boys $(n=80)$} & \multicolumn{2}{|c|}{ Girls $(n=89)$} & \multirow{2}{*}{$\mathbf{t}$} \\
\hline & M & SD & $\mathbf{M}$ & SD & \\
\hline $\begin{array}{l}\text { In selecting the marriage } \\
\text { partner Economic status of } \\
\text { the family must be counted }\end{array}$ & 3.25 & 1.22 & 3.36 & 1.18 & $0.62 *$ \\
\hline $\begin{array}{l}\text { Family finance should be left } \\
\text { to a wife to have economic } \\
\text { independence }\end{array}$ & 3.14 & 1.25 & 3.21 & 1.07 & 0.36 \\
\hline $\begin{array}{l}\text { In present days it is also a } \\
\text { duty of wife to support her } \\
\text { husband economically }\end{array}$ & 3.72 & 1.23 & 4.05 & 0.86 & $1.99 *$ \\
\hline
\end{tabular}

Note. Judgments were made on a 5 point scale $(1=$ strong disagreement, 3 $=$ neutral, $5=$ strong agreement). From "Values of college youth towards marriage", by P. R. Sumangla and S. Hasalkar, 1999, Journal of Avinashlingam Deemed University, 9, p. 165. Copyright 1999 by Avinashlingam Institute for Home Science and Higher Education for Women - Deemed University, Coimbatore - 641 043, Tamil Nadu, India. Reprinted with permission.

$* p<.01 * * p<.05$

relation before marriage with fiancé lessens the respect after marriage. Table 5 shows the perception of moral value of youth towards marriage.

\section{Economic value of marriage}

Marriage fulfils various needs of individuals. However, fulfilling the needs depends upon the economic resource that each partner brings in marriage. Table 6 shows that among girls, one of the strong feelings are their duty to support their husband economically. 


\section{Psychological and social values of marriage}

The other psychological values of marriage were found similar among boys and girls except in relation to sex. Boys expressed a strong agreement to the statement "Sex in marriage strengthens the love bondage between husband and wife." Also another statement to which they differed significantly from their counterparts was 'Sexual satisfaction is important in marriage'.

Regarding social values, mean scores of boys for the two statements namely "Women should tolerate ill treatment from her husband rather than going for divorce" and "Living together before marriage is essential" were found to be higher than girls'mean scores. The former attitude expressed by the boys revealed the male dominance and later attitude indicates the modification in the value of marriage. Similarly girls opinion towards "Hindu marriage is a religious tie but not a contract" and "Inter-caste marriage lessens the problem of dowry have shown the girls" concern towards dowry in marriage and the religious sentiment of marriage. The recorded mean scores for girls were found to be higher than boys (see table 7).

Another change in the traditional marriage pattern is visible in the practice of inspecting the prospective bride before marriage by the members of the bridegroom's family. A comparison of the difference between the joint and the nuclear families showed that the practice found greater spread in the nuclear families than in the joint families, indicating that nuclear families are more open to accepting new trends (Lal, 1989). Marriage is one of the most important family formation variables. The institution of marriage and the event of child bearing are considered so essential for family life that couples staying together without marriage, single parent families, and childless families are not accepted as complete or normal families (Tata Institute of Social Sciences

Table 7

Social Value of Youth Towards Marriage

\begin{tabular}{|c|c|c|c|c|c|}
\hline \multirow{2}{*}{ Statements } & \multicolumn{2}{|c|}{ Boys $(n=80)$} & \multicolumn{2}{|c|}{ Girls $(n=89)$} & \multirow{2}{*}{$\mathbf{t}$} \\
\hline & M & SD & $\mathbf{M}$ & SD & \\
\hline $\begin{array}{l}\text { Woman should tolerate ill } \\
\text { treatment from husband } \\
\text { rather than going for divorce }\end{array}$ & 2.40 & 1.33 & 1.84 & 1.13 & $2.92 * *$ \\
\hline $\begin{array}{l}\text { Hindu marriage is a religious } \\
\text { tie but not a contract }\end{array}$ & 3.68 & 1.24 & 4.04 & 1.00 & $2.10 *$ \\
\hline $\begin{array}{l}\text { Living together before } \\
\text { marriage is essential }\end{array}$ & 2.84 & 1.39 & 2.15 & 1.15 & $3.44 * *$ \\
\hline $\begin{array}{l}\text { Inter-caste marriage lessens } \\
\text { the problem of dowry }\end{array}$ & 3.14 & 1.19 & 3.56 & 0.98 & $2.52 *$ \\
\hline
\end{tabular}

Note. Judgments were made on a 5 point scale $(1=$ strong disagreement, 3 $=$ neutral, $5=$ strong agreement). From "Values of college youth towards marriage", by P. R. Sumangla and S. Hasalkar, 1999, Journal of Avinashlingam Deemed University, 9, p. 166. Copyright 1999 by Avinashlingam Institute for Home Science and Higher Education for Women - Deemed University, Coimbatore - 641 043, Tamil Nadu, India. Reprinted with permission.

$* p<.01 \quad * * p<.05$
[TISS], 1993). Within marriage women do not enjoy any reproductive rights, these are exercised by the husbands and their family members, both with regards to numbers, timings, and sex composition of the children. Though love marriages have gained momentum in recent times through the influence of print and electronic media, their characteristics remain distinctly similar to that of joint families which include emotional, instrumental, and financial assistance.

\section{Divorce}

In the Indian society, women derive their social status from their husbands. Since the time of Vedas ${ }^{2}$, the institution of marriage was of sacramental character among the Brahmins ${ }^{3}$. For others marriage was contractual. Divorce was, and still is, permitted among the scheduled castes and tribes. In contemporary India, there is now a legal provision for divorce. Studies from different parts of the country indicate that cases of marital disharmony or estranged marriages are increasing, but in the Indian urban and upper caste divorce as an alternative to marital problems is not widely put into practice (Mullatti, 1995).

Social relationships of the divorced couple often get disrupted. For example, mutual friends tend to take sides, holding one or the other partner responsible for the disruption. Well wishing friends try to bring a compromise between the spouses. One of the partners may be left virtually friendless and be forced to rebuild his entire social world.

The marital disruption also has a major impact on parent-child relations. They are predictive of the immediate and long term psychological and behavioral adjustment of children (Amato, 1993). Cooney (1994) found that the children's feelings about a given parent were strongly correlated to contact with that parent in divorced families, suggesting that family relationships may become more voluntary after divorce. In other words, the quality and frequency of contact, and therefore the relationship, is by choice.

In contemporary research, divorce and re-marriage are viewed not as single, static events, but as part of a series of transitions, modifying the lives of children. In addition to the trauma of divorce itself, the transition related to divorce often involves geographic moves, the addition of step-siblings and a new set of extended family members. Divorce followed by re-marriage can involve the introduction of parent figures with multiple roles and overlapping relationships. Taken together, these factors related to divorce have a direct impact on the life courses of children and may be specially challenging for the adolescent who is simultaneously involved in critical developmental transitions (Hines, 1997).

Husbands and wives go through high emotional tension. The husband's relationship is marginally affected, whereas the wife's drastically changes. The wife moves out of the

2 Veda - Ancient Hindu Scriptures. Four Vedas are known: Rigveda, Samaveda, Yajurveda, and Atharvaveda.

3 Brahmins - The highest caste of the four caste sistem of the Hindu society. 
husband's house. If they stay in the same town, she does not enjoy same trust, confidence, and closeness as her previous counterpart does. She cannot make friends with her male colleagues, nor with married couples as the other women consider her to be a husband snatcher.

\section{Interpersonal Relationships}

\section{Marital and Parental Relationships}

Husband-wife relationship is the basic and most important amongst the network of relationships on which a family revolves. Healthy relations facilitate the spouses not only to perform their roles effectively but also help in the proper socialization of the children. On the other hand, marital conflict leads to familiar disorganization and has negative consequences on the upbringing of children. Thus, the quality of interaction between a husband and a wife has repercussions on the whole family.

\section{Parent-Child Relationships}

Parent-children conflicts with regards to individual freedom and double standards giving greater freedom to sons than daughters, is a recurring feature and has been noted in many studies (Kurian, 1986). A girl child is allowed to remain a child only for short period of life. It is always stressed that her relationship with her natal home is temporary. Parents tend to discriminate among boys and girls not only in terms of reinforcing speech, activity and play, but also in terms of food, education and other material possessions in India. Many of the social customs and rituals favour or promote child abuse. Indian society makes a relative underestimation of girls and views them as a family liability. Girls get less autonomy and freedom from parents than boys (Ghadially, 1988).

\section{Sibling Relationships}

Sibling relationship is recognized as unique among close human relationships because siblings share a common genetic heritage and common early experience within the family. The exchange patterns of emotional support are established among the siblings during early years (Avioli, 1989). Sibling relationship is also marked by discord when paternal authority is weak or absent. Such conflict is an important dimension of sibling relations. Herzberger and Hall (1993a) state that boys and girls may have different expectations when siblings are involved in the conflict. Severe sibling violence was found to be more prevalent among boys. Furthermore, when younger children were victimized by an older sibling they sought help from parents. Thus, children recognized that aggression against younger siblings is wrong (Herzberger \& Hall, 1993b). As joint family system is one of the basic features of Indian society, it becomes essential to consider the cordial and conflicting relationship between secondary relatives.

\section{Mother-in-Law and Daughter-in-Law Relationships}

The mother-in-law occupies a dominant position and plays an important role in the social life of the daughter-in-law. This is one area where very few studies have been done. Srivastava (1974) in his comparative study of folk cultures of Rajasthan and Uttar Pradesh (states of central India) reported that in both the regions, usually the mother-in-law kept severe control over the daughter-in-law. The elder woman finds the younger was disrupting unity among brothers; the younger finds the elder to be intolerably demanding and dominating (Madan, 1965). The relationship of women with sisters-in-law is another area which has dearth of studies although it is of great significance in a joint household.

\section{Contemporary Issues}

\section{Problems Faced in Family Relationships}

\section{Marital problems}

A background of patterns of marital interactions, roles, and power in India is essential before we review research on marital problems. However, studies on family in India have generally concentrated on the joint family, with a patriarchal structure. It has been largely recognized that conjugal relations have little significance in the joint family (Ramu, 1988). Consequently, marital interaction, role, and power have received scant attention. The few studies that are identified in this area are grouped and described below.

\section{Marital adjustment versus maladjustment}

Marital adjustment refers to a state of accommodation which is achieved in different areas where conflict may exist. Srivastav, Singh, and Nigam (1988) studied the effect of certain demographic characteristics such as age differences, duration of marriage, education, occupation, socio-economic status, and number of children on marital adjustment. The analysis indicated that age difference between husband and wife highly contributed towards marital adjustment. Secondly, differences in educational level of the spouses were more evident in the maladjusted couples. Shukla (1988) observed that as compared to the single career couples, more of the dual career couples expected that the husband and the wife should be about equally responsible for the provider and the housekeeper roles, and evaluated the wives more favorably in the provider role and the husbands in the housekeeper roles. It is interesting, though, that in both the groups, wives derived greater happiness in their marriages when they were satisfied with the housekeeper role and evaluated their husbands favorably in the provider role. Husbands, on the other hand, attached greater importance to satisfaction with and a favorable evaluation of themselves in the provider role and their spouses in the kinship roles. Thus, the working woman ends up playing a multiplicity of roles. According to this author, the women workers expressed that they had 
unsatisfactory relationship with their husbands (72\%), children $(72 \%)$, and in- laws (22\%). The main reasons behind the unsatisfactory relationship were lack of time to interact freely with husband and lack of time to provide adequate love and care for their children. The other reasons were physical and mental exhaustion due to heavy and never ending work, indifferent attitudes of their husbands and in-laws towards their over work and inability both of them to gain control over the women workers earnings.

In another study, Mohan and Singh (1985) studied mental adjustment of rural and urban couples in relation to their personality in terms of extroversion, neuroticism, and psychotism. The analysis showed that rural couples were better adjusted than urban. Kumar and Rohtagi (1984) studied the dominance need of spouses and also attempted to identify personality factors such as intelligence and extroversion with reference to adjustment in marriage. It was found that husbands with high adjustment possessed a higher need of dominance, whereas wives with high adjustment were submissive. It was found also that couples with high adjustment were more intelligent, possessed high extroversive interest as compared to couples showing low adjustment. Kumar and Rohtagi (1985) examined the relationship of anxiety, neuroticism and security variables with adjustment in marriage and showed that anxiety affects one's adjustment in marriage.

\section{Family Violence}

Family violence is a complex concept which encompasses wife abuse, child abuse, and elderly abuse. Pagelow (1981, p. 437) defined family violence as "any act of commission or commission by family members and any condition resulting from such acts and inaction which deprive other family members of equal rights and opportunities and/or interfere with their optimal development and freedom of choice."

Violence on women in the family has existed over centuries and across the world. It has recently been recognized by the United Nations (1995) as a fundamental abuse of women's human rights. It lists under the category of gender based violence, abuses such as battering, sexual abuse of female children, dowry related violence, marital rape, and female genital mutilation. Female infanticide is still common in some pockets of the country. In recent years, new forms of violence have been added to the list. Most important among these are dowry deaths and female feticide. Heife, Pitanguy, and Germaine (1994, paper 225) describe violence against women as "any act of verbal or physical force, life threatening deprivation directed at an individual women or girl that causes physical and psychological harm, humiliation or arbitrary deprivation of liberty that perpetuates female subordination."

In 1995, more than 24,000 complaints were filed with the Crime Against Women Cell, in Delhi, relating to marital disputes ranging from cruelty to misappropriation of stridhan $^{4}$. The situation continues to decline further. The latest reports indicate that crime against women rate is $34.1 \%$ in Delhi and also that it has the highest dowry death rate in the country (Delhi, 1997).

Steinmetz and Lucca (1988) stirred a controversy by reporting that men do not have a monopoly as tormentors. Rather, they found a considerable similarity between husbands and wives using violent methods for resolving marital conflicts. Nevertheless, though women may be more verbal, the resort to physical means to maintain their dominant position in the family is held by men (Gandhi, 1997). According to Gandhi, factors related to poverty and lack of education among women make them more vulnerable to violence. Thus, elimination of violence against women requires reengineering of society on equalitarian values, where women enjoy equal rights over education, land, property, and business. The creation of such a society needs the support of all, including men.

\section{Effect of Family on Child Development}

In a joint family, the child gets multiple parents and many adult figures for his or her identification. In these families, children are overprotected and sheltered and, as a result, selfnon-self segregation is hampered. In a nuclear family, the child has a limited set of adult models to emulate. As a result, he or she develops a strong sense of personal bond with the parents, with a greater scope of developing clear-cut selfidentity (Sinha, 1984). Children brought up in single parent families have only one adult member in the family and often lack kinship and community support. These children develop early independence with added responsibilities. A majority of the single parent families being the poorest of the poor cannot adequately meet their children's needs. A large number of children in institutions and on streets come from single parent families.

Thus, to enhance the impact of child development, direct work with children is not adequate. The family life and the family's environment also have to be enriched. A strong family unit would promote child development and prevent child destitution.

\section{The Elderly's Need of a Family and Abuse of Elders}

In the Indian context, responsibility for care of the elderly is primarily borne by members of the family. A legal provision allows the old person to claim maintenance from his/her children, if he or she has no resources of his/her own (Section 125 of the Code of Criminal Procedure, 1973, as cited in Diwan \& Kumar, 1984). However, few parents go to court to claim maintenance from their children.

The Constitution of India recognizes the duty of the State towards the elderly. "The State shall within the limits of economic capacity, and development, make effective provision for securing the right to work, to education, and to public assistance in case of unemployment, old age, sickness and dis-

4 Stridhan is the gift given to the bride by her parents on her marriage. 
ablement and in other cases of undeserved want" (Constitution of India, Article 41, as cited in Pylee, 1979, p. 471). Traditionally, the aged in India continue to live in their homes where they have been living throughout their lives. The family, the neighborhood, and the community provide ample opportunities for companionship and social life. Even today the family, the kinship group, the neighborhood, and the community continue to contribute to the psychological and social wellbeing of the old. Most of the investigations in India suggest that the aged are respected, consulted on important decisions (even if it is a token gesture), and continue to be heads of households.

Some factors - outcomes of increased urbanization - have adversely affected older people. One is the migration of the younger adults of the family to towns and in some cases to foreign countries, in which case the older generation loses the support of their children, if they are left behind (see Table 8 ). The older generation may be reluctant to migrate, either because of shortage of housing in towns or because of difficulty in adjusting to the life style in new setup.

The increased participation of women in paid employment outside the home is another factor that has affected old people in urban areas (Ramanujam, Gupta, \& Mamgain, 1990). On the positive side, parents are wanted and made to feel useful when they take up responsibilities of caring for the grandchildren, and helping with the running of the house. The flip side is that women, who have been the traditional caregivers, are now not available for that role, and the old people are left to fend for themselves. The well-being of old people may also be affected by their own personality problems. If the person has not maintained a good relationship with his or her family members throughout life, then it becomes difficult to improve relationships in later period.

Elderly people experience a stage of transition from independence to interdependence, then to total dependence, which produces a crises and tension for all generations (Steinmetz, 1988). The sex of the old person also becomes an important risk factor for abuse. It has been found that elderly females are more abused than males (Dudley, 1983). Consequently, widows have to depend upon others and spend later years of their lives in very pitiable conditions (Mahadevan \& Sumangale, 1992). The tradition of obligatory dependence on male children is perhaps the bane of old age despite increasing evidence in recent times that daughters are coming forward to assume the responsibility of providing support to their elderly parents when they are abandoned by their son(s).

\section{Migration and Displacement of the Family}

Migration has fundamental implication for women and children. They suffer when the male migrates either alone or with them. The kinship network is broken and the traditional skills are no longer useful in the urban economy (Desai, 1995b). However, it has also been suggested that rather than family disintegration, male migration could lead to more capable and self confident women. This analysis is based on three factors: guardianship of family, residential arrangement, and manage-
Table 8

Reasons for Migration

\begin{tabular}{lrcrc}
\hline \multirow{2}{*}{ Reason } & \multicolumn{2}{c}{ Rural } & \multicolumn{2}{c}{ Urban } \\
\cline { 2 - 5 } & Males & Females & Males & Females \\
\hline Employment & 20.07 & 1.28 & 43.10 & 4.24 \\
Education & 4.06 & 0.46 & 6.81 & 2.40 \\
Family moved & 33.23 & 9.61 & 26.89 & 32.07 \\
Marriage & 4.87 & 79.47 & 1.05 & 46.78 \\
Others & 37.77 & 9.18 & 22.15 & 14.51 \\
\hline
\end{tabular}

Note. From Census of India (Occasional paper no. 1, p. 1-615), by Ministry of Home Affairs - Social Studies Division, 1991, New Delhi: Author. Copyright 1991 by Registrar General of India. Reprinted with permission.

ment of major household activities. Nevertheless, it has been observed that after the return of the emigrant husbands, although the wives continue to participate in decision making, the execution of major household activities was taken over by their male counterparts (Sekhar, 1996).

\section{Conclusion}

Family has been recognized as a basic unit of society and is a link between individual and community. The structure of the family continues to be patriarchal. A number of changes have been observed in the patterns of marriage such as age at marriage, inter-caste marriage, etc. A relative increase is noticed in divorce cases in urban areas. It was quite common in the past but at that time families were more stable and provided adequate security in terms of physical, social and emotional needs. Current trends indicate that there is a definite change in the basic system of family, especially the role of elders and disharmony in husband-wife relationship. Divorce rates are testimony to the increasing fragility of husband-wife relationship. Migration has major implications on women and children.

Although children in several set-ups, women, and the elderlies have been the subjects of various studies, investigations on the family as a whole are clearly very limited. There seems to be a general paucity of applied family research in India. Thus it is important to deliberate whether these studies can be considered applied in nature - applied research is oriented towards outcome, rather than concepts, and it begins on the premise of usefulness and application. There is, therefore, a need to bring together under one umbrella, all research efforts which focus on specific aspects of family with the aim of influencing family practices and family policy development.

\section{References}

Amato, P. (1993). Children's adjustment to divorce: Theories, hypothesis and empirical support. Journal of Marriage and Family, 55, 23-38.

Avioli, P. S. (1989). The social support functions of siblings in later life. American Behavioral Scientist, 33, 45-57.

Basaiawmoit, E. R. (1987). An attitude of the matrilineal system and its implication for education. Unpublished doctoral dissertation, North Eastern Hill University, Shillong, India. 
Bharat, S. (1994). Alternate family patterns and policies: Alternate family pattern (Unit for Family Studies Report, pp.7276). Bombay, India: TISS.

Cooney, T. M. (1994). Young adult's relation with parents: The influence of recent parental divorce. Journal of Marriage and Family, 56, 45-56.

Delhi has the highest dowry death rate in the country (1997, March 8). The Times of India, p. 17.

Desai, A. R. (1980). Urban family and family planning in India. Bombay, India: Popular Prakashan.

Desai, M. (1994). Concept and conceptual frameworks for understanding family. Enhancing the role of the family as an agency for social and economic development (Unit for Family Studies Report, pp.16-41). Bombay, India: TISS.

Desai, M. (1995a). Towards family policy research. Indian Journal of Social Work, 56, 225 - 231.

Desai, M. (1995b). National observance of the international year of the family. Indian Journal of Social Work, 56, 233-246.

Diwan, P., \& Kumar, V. (1984). (Eds.). Law towards stable marriages. New Delhi, India: Seema.

Dudley, A. (1983). Relationship with male and female elders. Smith College Studies in Social Work, 53, 177-87. (From Sociological Abstracts, 1987, Abstract No. 35)

Gandhi, A. (1997). Violence against women, with reference to 498 A and 304 B, Indian Penal Code. Indian Journal of Social Work, $58,582-597$.

Ghadially, R. (1988). Women in Indian society. New Delhi: Sage.

Gulati, L. (1995). Women and family in India - continuity and change. Indian Journal Social Work, 56, 134-154.

Heife, L., Pitanguy, J., \& Germaine, A. (1994). Violence against Women - The Hidden Health Burden (World Bank Discussion Paper 255). Washington, DC: World Bank.

Herzberger, S. D., \& Hall, J. A. (1993a). Children's evaluations of retaliatory aggression against siblings and friends. Journal of Interpersonal Violence, 8, 77-93.

Herzberger, S. D., \& Hall, J. A. (1993b). Consequences of retaliatory aggression against siblings and peers: Urban minority and children's expectations. Child Development, 64, 1773-1785.

Hines, A. M. (1997). Divorce-related transition, adolescent development, and the role of the parent-child relationship: A review of the literature. Journal of Marriage and Family, 59, 375-388.

Kapadia, K. M. (1982). Marriage and family in India. Calcutta, India: Oxford University Press.

Kolenda, P. (1987). Regional differences in family structure in India. Jaipur, India: Rawat Publications.

Kumar, P., \& Rohtagi, K. (1984). Certain personality correlates of marital adjustment. Indian Journal of Social Work, 45, 325-330.

Kumar, P., \& Rohtagi, K. (1985). Marital adjustment: Study of some personality correlates. Indian Journal of Clinical Psychology, 12, 15-18.

Kurian, G. (1986). Intergenerational integration with special reference to Indian families. Indian Journal of Social Work, 47, 39-49.

Lal, A. K. (1989). The urban family. New Delhi, India: Concept Publishing House.

Madan, T. N. (1965). Family and kinship: A study of the pundits of rural Kashmir. New York: Asia Publishing House.

Mahadevan, K., \& Sumangala, M. (1992). Approaches to the study of the elderly population. In P. Krishana (Ed.), The elderly population in developed and developing world (pp. 510). New Delhi, India: B. R. Publishing House.
Ministry of Home Affairs - Social Studies Division. (1991). Census of India (Occasional paper no. 1). New Delhi, India: Author.

Mohan, V., \& Singh, S. (1985). Eysenck's personality dimensions as related to marital adjustments. Indian Journal of Community Guidance Service, 2, 25-33.

Mullatti, L. (1995). Families in India: Beliefs and realities. Journal of Comparative Family Studies, 26, 11-25.

Pagelow, M. D. (1981). Women battering: Victims and their experience. Beverly Hills, CA: Sage.

Pylee, M. V. (1979). India's constitution. Bombay, India: Asia Publishing House (P) Ltd..

Ramanujam, M. S., Gupta, R., \& Mamgain, R. P. (1990). Empowerment of women. Manpower Journal, 26, 48-80.

Ramu, G. N. (1988). Wife's economic status and marriage power: A case of single- and dual-earner couples. Sociological Bulletin, 37, 49-70.

Saiborne, I. (1995). Perception towards the changing roles of the Khasi males in the matrilineal families of Meghalaya. Unpublished master's thesis, S.N.D.T. Women's University, Bombay, India.

Sekhar, T. V. (1996). Male emigration and changes in the family: Impact on female sex roles. Indian Journal of Social Work, 57, 277-294.

Shukla, A. (1988). Marital role behaviors and marital relationship among single and dual career families. Indian Journal of Clinical Psychology, 15, 84-88.

Sinha, D. (1984). Some recent changes in the Indian family and their implications for socialization. Indian Journal of Social Work, 45, 271-285.

Sriram, R. (1993). Family studies in India: Appraisal and new directions. In T. S. Saraswati \& B. Kaur (Eds.), Human development and family studies in India: An agenda for research and policy (pp. 122-128). New Delhi, India: Sage Publishers.

Srivastav, D., Singh, S. B., \& Nigam, J. C. (1988). Demographic characteristics and marital adjustment. Indian Journal of Clinical Psychology, 15, 89-91.

Srivastava, S. L. (1974). Folk culture and oral tradition. New Delhi, India: Abhinav Publications.

Steinmetz, S. K. (1988). Duty bound: Elder abuse and family care. Newbury Park, CA: Sage Publications.

Steinmetz, S. K., \& Lucca, J. S. (1988). Husband battering. In V. B. Van Hasselt, R. L. Morrison, A. S. Bellack, \& M. Hersen (Eds.). Handbook of family violence (pp. 233-246). New York: Plenum Publishing.

Sumangla, P. R., \& Hasalkar, S. (1999). Values of college youth towards marriage. Journal of Avinashlingam Deemed University, 9, 162-167.

Tata Institute of Social Sciences [TISS]. (1993). Approach paper for plan of action in the international year of the family in 1994 and beyond (Report No. 1). Bombay, India: Author.

United Nations. (1995). Focus on women and violence. Paper presented at the $4^{\text {th }}$ World Conference on Women, Beijing, China.

Received October 30, 2000

Revision received January 16, 2001

Final version February 8, 2001

Accepted June 6, 2001 